\title{
Opinion
}

\section{Epidemiological profile in multiple sclerosis patients, Uberaba, MG, Brazil}

\section{Anderson Kuntz Grzesiuk}

\section{Dear Editor,}

We read with great interest the article published by Ribeiro SBF et al. (Arq Neuropsiquiatr 2011;69:184-187), about the epidemiological characteristics of patients with multiple sclerosis (MS) in the city of Uberaba-MG, Brazil. In this article, the authors comment on the similarity of most of the clinical and epidemiological features found in Uberaba to those presented in other samples in Brazil. However, when considering ethnicity, which in their study was predominantly Caucasian (85.71\%), they cite the example of the city of Recife, where the incidence was predominantly in the black population (93.3\%). They also mention the difficulties of ethnic classification in the Brazilian population, given the racial characteristics observed in our population.

We agree that these difficulties exist but, nonetheless, we believe that ethnic traits need to be better studied in Brazil, with regard to the therapeutic options for multiple sclerosis. This can be seen from a study by Alves-Leon et al. ${ }^{1}$, in which they demonstrated the existence of heterogeneous phenotypes of HLA-DRB1*1501 in a population of healthy Brazilians that included both African descendants and white subjects. It is known that these alleles can negatively influence the therapeutic response to interferon. In another study, Brum et al. ${ }^{2}$ drew attention to the fact that HLA-DRB1 may exhibit behavior of either resistance or susceptibility in response to ethnic background and environmental factors.
Brazil is a country of continental dimensions with a high degree of miscegenation. However, this miscegenation is variable with regard to demographic distribution. Ethnic characteristics need to be reviewed more carefully because surveys on the epidemiology of MS in some Brazilian cities have found that the rate of cases of MS among the black population was greater than that observed in other studies, especially in the cities of Rio de Janeiro $(28 \%)^{3}$ and Cuiabá $(26 \%)^{4,5}$. This implies that there is a need for regional and multicenter studies on MS in Brazil, especially in relation to the genetic susceptibility and environmental variables observed in a country with the dimensions of Brazil.

Our congratulations to the authors.

\section{REFERENCES}

1. Alves-Leon SV, Papais-Alvarenga R, Magalhães M, Alvarenga M, Thuler LC, Fernández Y Fernández O. Ethnicity-dependent association of HLA DRB1DQA1-DQB1 alleles in Brazilian multiple sclerosis patients. Acta Neurol Scand 2007:115:306-311.

2. Brum DG, Barreira AA, Louzada-Junior P, Mendes-Junior CT, Donaldi EA. Association of the HLA-DRB1()15 allele group and the DRB1()1501 and DRB1()1503 alleles with multiple sclerosis in White and mullato samples from Brazil. J Neuroimmunol 2007;189:118-124.

3. Papais-Alvarenga RM, Santos CMM, Abreu JS, et al. Esclerose múltipla (EM): Perfil clínico e evolutivo no município do Rio de Janeiro. Rev Bras Neurol 1995;31:75-87.

4. Grzesiuk AK. Características clínicas e epidemiológicas de 20 portadores de esclerose múltipla acompanhados em Cuiabá-Mato Grosso. Arq Neuropsiquiatr 2006;64:635-638.

5. Grzesiuk AK, Siqueira HHF, Silva NM, Catarino KCP, Martins PM. Prevalência da Esclerose Múltipla na cidade de Cuiabá-MT - 2007. O Dendrito 2008;14:35-37. 